A CoMmitTeE of the National Academy of Sciences last week shook the foundations of energy planning in the United States by suggesting that domestic supplies of oil and gas may dry up in 25 to 30 years, much sooner than the government has been forecasting. If the committee's estimates turn out to be correct, deep trouble is in store for the much-vaunted drive to make the United States less dependent on imported oil to meet its energy needs.

The estimates form part of a 2-year review of minerals supply and demand, conducted by the academy's Committee on Minerals Resources and the Environment (COMRATE). The committee's central, and inescapable, conclusion is that much more vigorous conservation efforts are needed, not only for oil and gas, but for varicus other materials as well. As COMRATE's chairman, Dr Brian J. Skinner, professor of geology and geophysics at Yale University, put it last week, conservation should become "almost a religion" if serious dislocations are to be avoided.

Although there is no single "official" estimate of oil and gas resources in the United States, those most commonly used for government planning have been developed by scientists working for the US Geological Survey (USGS). The USGS figures generally suggest that domestic production of oil and gas can be expanded over the next decade, and that supplies will be good for at least 40 or 50 years.

But those forecasts have been challenged recently by much of the oil industry and a number of distinguished experts. They have argued that the USGS's estimates are grossly overblown and that domestic resources are already beginning to dry up. COMRATE's entry into the fray last week with an estimate that broadly supports USGS's critics is likely to sharpen the debate considerably.

The importance of the dispute is this. If the USGS's figures are correct, expansion of oil and gas production in the United States over the next decade or so will be a great help in alleviating dependence on Arab oil. Projections developed last year by the Federal Energy Administration, for example, envisaged domestic oil and gas production going up by more than $50 \%$ by 1985 , given the economic incentive of high oil prices and some governmental support. But if the USGS's critics are correct, expanded domestic production can be virtually ruled out. Moreover, there will be an acute need to develop alternative fuels (such as synthetic petroleum and gas from coal, and oil from shale) as quickly as possible.

There is virtually no dispute about the size of the so-called "proven" reserves-those which the oill industry

\title{
Bad news for US energy planners
}

\author{
by Colin Norman, Washington
}

has already found and believes it can exploit commercially with conventional technology. The nub of the disagreement concerns the extent of oil and gas deposits which have yet to be discovered-the so-called undiscovered recoverable resources.

In March last year, USGS Director Vincent McKelvey published a set of figures suggesting that undiscovered oil resources in the United States and offshore amount to between 200 and 400 billion barrels, while undiscovered naturall gas resources total between 990 and 2,000 tritlion cubic feet. By comparison, estimates developed by two oil companies last year put the oil reserves at about 90 billion barrels and gas reserves at about 400 trillion cubic feet. Now COMRATE has come up with a forecast that about 113 billion barrels of oil and 530 trillion cubic feet of gas remain to be discovered.

Surprisingly, those estimates differ little on the extent of oil and gas resources in Alaska and offshore, although COMRATE estimates that fully $70 \%$ of future supplies will come from those areas. The chief discrepancy is to be found in the forecasts for the extent of undiscovered deposits onshore in the lower 48 states, and that fact is surprising because the continental United States is about the most extensively drilled area in the world.

The difference is explained by the fact that there are two schools of thought about how the resources should be measured. The oil industry says that the USGS estimates fail to take sufficiently into account the trend of declining oil production per foot of drilling over the past few years, while the USGS says that the oil industry's estimates pay insufficient attention to potential production from small fields.

Until recently, USGS's figures were based essentially on a method which involves extrapolating production rates for oil and gas from known fields to similar geological deposits elsewhere. But that methodology has come under increasing attack, most prominently by M. King Hubbert, a geologist who used to work for Shell, but who now works for the USGS. Hubbert maintained, as long ago as the $1950 \mathrm{~s}$, that such predictions are based on production data from the richest parts of existing fields, and thus fail to take into account the fact that the amount of oil produced per well in a given field declines with the number of wells drilted. In other words, the oil com- panies have creamed off the most productive areas of Texas, Oklahoma and California and information from those areas is unreliable as a guide to what is likely to be found elsewhere.

The USGS's more recent estimates have gone some way towards meeting Hubbert's objections, since they assume that unexplored areas will be only about half as productive as areas which have already been exploited. But Hubbert argues that even those revised estimates will prove to be much too optimistic. A better estimate, he says, is that they will be about one tenth as productive.

Hubbert has at least one important piece of evidence in his favour. In the mid 1950s, he predicted that domestic oill production in the United States would peak in the late 1960s and thereafter would decline; the USGS was then estimating that the peak would not come until the mid-1980s at least.

As it turned out, the peak came in 1970. Hubbent's critics point out that environmental constraints, coupled with a moratorium on offshore oil drilling, may have been responsible for some of the decline since 1970 , but Hubbert's arguments have steadily gained acceptance in the oil industry, and in particular they have forcefully been taken up by John Moody, a former official of Mobil Oil and now a consultant to the oil industry. Moody, who was a member of the COMRATE panel, estimated last year that undiscovered oil reserves amount to about 90 billion barrels.

For its part, COMRATE has come close to accepting the validity of Hubbert's approach. Its report states that the projections developed last year by McKelvey "could have been more rigorously derived" and COMRATE's estimate that undiscovered reserves amount to about 113 billion barrels is closer to Hubbert's prediction than to that of the USGS.

Asked what effect he expects the COMRATE report to have, Skinner said last week that "now that the National Research Council (the operating arm of the National Academy of Sciences) has put out a report that comes down in favour of the lower figures, not firmly but at least in favour of them, there will be a lot of pressure on the Geological Survey to justify its methods".

A USGS official noted, however, that oil resources have consistently been underestimated by the oil industry in the past. "Who is to say who is right?", he said, "We are not going to back off from those figures just because they are high". The USGS is, however, updating its estimates and hopes to have a new set of figures, based on the most recently available geophysical data, ready by April. 